\title{
観測地下水位による自由地下水場の基盤高と 地下水パラメータの推定について
}

\author{
藤野和德 $*$ 小路順一 $* *$ \\ Identification of Lower Boundary of Aquifer \\ and Groundwater Parameters in Unconfined Aquifer \\ by Genetic Algorithm
}

\author{
Kazunori $\mathrm{FUJINO} \mathrm{*}$ and Jun-ichi SHOJI **
}

\begin{abstract}
In this paper, using several observed groundwater levels, the method to identify the distribution of the lower boundaries of aquifer and the groundwater parameters in unconfined aquifer simultaneously is proposed. The genetic algorithm is used to minimize the difference between the observed and the calculated groundwater levels. Here the distribution of the lower boundaries of aquifer is expressed by linear interpolation of several lower boundaries on the grids and the groundwater parameters are constant in the region. This method is applied to the simulation regions of aquifer and coastal aquifer to discuss the availability.
\end{abstract}

Key Words: Observation Groundwater Level, Unconfined Aquifer, Hydraulic Conductivity, Effective Porosity, Lower Boundary of Aquifer, Genetic Algorithm

\section{要 旨}

この研究は数箇所の観測地下水位を用いて、自由地下水場の帯水層の基盤高と地下水パ

* 八代工業高等専門学校土木建築工学科（

Department of Civil and Architectural Engineering, Yatsushiro College of Technology

**アジアプランニング(株)

Asia Planning, Inc,. 
ラメータを同時に同定する手法を提案している。遺伝的アルゴリズムを観測地下水位と推 定地下水位の差を小さくするために使用している。ここで、基盤高の分布は数箇所の基盤 高より線形補完して抢り、また、地下水パラメータである透水係数、有効空隙率は解析領 域内では一定としている。この手法を淡水のみの帯水層および海岸近くの帯水層に適用し その有效性を検討している。

キーワード：観測地下水位、自由地下水、透水係数、有効空隙率、基盤高、遺伝的アルゴ リズム

\section{1. はじめに}

自由地下水場において地下水の流れを解析した り、地下水污染対策のために地下水中の物質の挙 動を解析する場合、境界の地下水位、地下水パラ メー夕 (透水係数、有効空隙率)、基盤高が必要 となる。これまで地下水パラメータについては揚 水試験によって直接求めたり、また、間接的に地 下水の流れを規定する方程式と地下水位の観測結 果をもとに逆解析手法によって求められている。 この逆解析手法には多くの研究があり、大西・井 尻（1986）は非線形計画を用いて、平野（1991）、 藤野・神野 (1994) はカルマンフィルターを用い て、竹下ら（1997）は遺伝的アルゴリズムを用い て地下水パラメータを推定している。また、藤間 (1989)、神野 (1990) の研究があり、本城 (2000)、竹下 (2000) はこれまでの逆解析手法を まとめている。

基盤高もまた地下水の流れを規定するものであ り、被圧地下水であれば透水係数と带水層厚の積 である透水量係数によって地下水の流れを解析す ることができる。しかしながら自由地下水では帯 水層厚は地下水位の関数であることから透水量係 数を定義することができない。地下水位の変動が 小さい場合は平均地下水位を近似的に帯水層厚と して取り扱う場合はあるが、精度よく解析するに は透水係数と基盤高をそれぞれ与える必要があ る。基盤高や帯水層厚はこれまでボーリング調査 によってのみ求められており、基盤高を、また基 盤高と地下水パラメータを同時に逆解析手法で求 めている研究は見受けられない。実際問題として 自由地下水場で地下水の流れを精度よく解析する
場合は、精度よい基盤高分布が必要であるが、多 くの場合数点のボーリング調査結果から解析領域 の基盤高分布を概略与え、地下水位や地下水の流 向を求めているのが現状である。基盤高や帯水層 厚を求めるには多くのボーリング調査が必要であ るが、これには多くの費用を必要とする。

したがって、本研究は観測された地下水位には 地下水定数や基盤高の情報が内包されていること を利用し、遺伝的アルゴリズム（北野 (1994)) を 用いて、自由地下水場に扔ける基盤高抢よび地下 水パラメー夕を同時に推定する手法を提案するも ので、シミュレーションモデルを用いて本手法を 検討している。本手法の利用価值としては、既存 の基盤高分布の評価や新たに基盤高分布を求める ためのボーリング調査の補完に役立つものと考え る。

\section{2. 遺伝的アルゴリズムによる基盤高と地下水パ ラメータの推定手法}

地下水パラメー夕、基盤高分布、境界条件が正 しく設定されれば、地下水位の挙動は地下水流方 程式や地下密度流方程式を用いて計算することが できる。観測地下水位には地下水パラメータおよ び基盤高分布の情報が内包されており、本研究は 基盤高分布および地下水パラメータの組み合わせ を数多く与え、遺伝的アルゴリズムにより、算定 された地下水位が観測水位に一致するようなパラ メータの組み合わせ、すなわち基盤高分布と地下 水パラメー夕を同定する手法を提案するものであ る。遺伝的アルゴリズムは適応度の高い近似解を 得るもので、数学的取り扱いが簡単であり、適応 
関数を設定することができればどのような問題で も解を得ることができることから、探索手法に遺 伝的アルゴリズムを用いている。

ここでは 1 次元のシミュレーションモデルは海 岸地域で地下水位が観測された場合を取り扱い、 地下水位を規定する方程式に地下密度流方程式を 用いている。平面 2 次元のシミュレーションモデ ルは内陸部に扔いて地下水位が観測された場合を 取り扱い、自由地下水の地下水流方程式を用いて いる。両モデルともに高さ方向には流速は変化し ない（垂直流速を無視）とした準一様流が適用で き、観測水位とボーリング調査結果から既知の基 盤高をもとに、基盤高分布拉よびシミュレーショ ン領域内で一定の地下水パラメータである透水係 数と有効空隙率を同時に同定する手法を提案して いる。なお、一般に観測地下水位には観測誤差や 準一様流の仮定による誤差雑音が含まれている可 能性があるが、本研究では予め誤差の取り除かれ た観測地下水位をもとに、実務的に基盤高および 地下水パラメータの同定に焦点をあてている。

図 1 に示す 2 次元のシミュレーションモデルを 用いて基盤高、地下水パラメータの同定手法を図
2 にしたがって説明する。このモデルでは、地下 水位観測点は 7 箇所、既知の基盤高位置は 5 箇所 となっている。基盤高分布は図 1 のと印の 15 点を線形補完して表すこととしており、そのうち の 5 箇所が既知としているため、残り10箇所の基 盤高を求めることになる。また、地下水パラメー 夕数は透水係数と有効空隙率の 2 つで、したがっ て合計 12 個のパラメー夕を求める問題となってい る。

遺伝的アルゴリズム（北野、1994、藤野、 1997）は生物の進化論をもとに構成されたもの で、一般的に 3 つの過程、選択、交叉、突然変異 によって、適合する子孫到達の原理をモデリング した確率的探索手法である。ここでは初期に遺伝 子として様々な基盤高と地下水パラメー夕を持っ た生物群が世代を追うに従い、適合する生物群す なわち観測された地下水位とょく一致する基盤高 と地下水パラメー夕を持った生物群に変わってい き、その生物群を明らかにすることによって基盤 高と地下水パラメー夕を求めるものである。

処理手順として、まず、初期個体集団を生成す る。パラメー夕は計算の便宜上全て 8 桁の 2 進数

B4 不透水壁

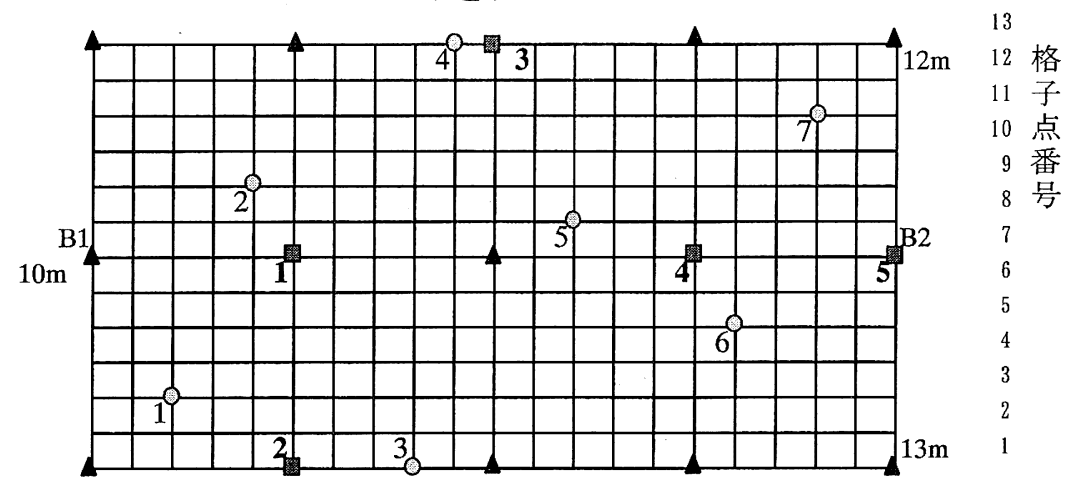

B3 不透水壁

\begin{tabular}{|c|c|c|}
\hline \multicolumn{3}{|c|}{$\begin{array}{lllllllllllllll}1 & 2 \\
\text { 格子点番号 } & { }^{2} & 6 & 7 & 8 & 9 & 10 & 11 & 12 & 13 & 14 & 15 & 16 & 17 \\
\text { 格子間 }\end{array}$} \\
\hline $\begin{array}{c}\text { 格子点番号 } \\
\text { B1 }\end{array}$ & 一定境界水位 10m & 格子閒 \\
\hline $\mathrm{B} 2$ & 一定境界水位 $12 \sim 13 \mathrm{~m}$ と & 直線的に変 \\
\hline 0 & 観測井戸位置 & 7 箇所 \\
\hline 图 & 既知基盤高位置 & \\
\hline$\Delta$ & 同定する基盤高の位置 & 10 箇所 \\
\hline
\end{tabular}

图 12 次元シミュレーション領域

Fig. 12 dimensional simulation region 
で表すことにした。したがって、1個体は12個の パラメータからなることから合計96 $(12 \times 8)$ 椼 の 2 進数（00101100……01010010）で表した。初 期個体集団は100個体とした。1個体は10箇所の 基盤高と透水係数、有効空隙率からなり、探索範 囲は解析領域の現地調査をもとに設定する必要が あるが、ここでは基盤高は基準高さから $0 \mathrm{~m}$ $5.5 \mathrm{~m}$ の範囲に、透水係数は $1 \sim 51 \mathrm{~m} /$ 日の範囲 に、有効空隙率は $0.2 \sim 0.4$ の範囲にあるとして、 $0 \sim 255$ (2 進数 8 桁を10進数に直した值)の乱数 を与えて各個体のパラメータを設定し、遺伝的ア ルゴリズムのパラメータとしてはこれを 2 進数表 示して用いている。

基盤高 $\quad 0$ から 255 の一様乱数 $\times 5.5 \mathrm{~m} / 255$

透水係数 0 只ら 255 の一様乱数 $\times 50 \mathrm{~m} /$ 日/ $255+1.0 \mathrm{~m} /$ 日

有効空隙率 0 から 255 の一様乱数 $\times 0.2 / 255+$ 0.2

次に、各個体（地下水パラメータと10箇所の基 盤高）の12個のパラメータと初期、境界条件を与 え、式 (1) を差分化した式 (1)’によって推定地 下水位を求める。

$$
n \frac{\partial h}{\partial t}=k \frac{\partial}{\partial x}\left\{(h-g) \frac{\partial h}{\partial x}\right\}+k \frac{\partial}{\partial y}\left\{(h-g) \frac{\partial h}{\partial y}\right\}+r
$$

ここに、

$h$ : 地下水位 $(\mathrm{m})$

$g \quad$ : 基盤高 $(\mathrm{m})$

$k$ : 透水係数 $(\mathrm{m} /$ 日)

$n$ : 有効空隙率

$r$ : 涵養量 $(\mathrm{m} /$ 日)

式（1）の差分式は、次式で与えた。

$$
\begin{gathered}
h(x, y, t+\Delta t)=h(x, y, t)+\frac{k \cdot \Delta t}{n \cdot \Delta x^{2}}(e 1 \cdot g 1-e 2 \cdot g 2) \\
+\frac{k \cdot \Delta t}{n \cdot \Delta x^{2}}(e 3 \cdot g 3-e 4 \cdot g 4)+\frac{\Delta t}{n} r
\end{gathered}
$$

ここに、

$$
\begin{aligned}
& e 1=\frac{1}{2}\{(h(x+\Delta x, y, t)-g(x+\Delta x, y))+(h(x, y, t)-g(x, y))\} \\
& g 1=h(x+\Delta x, y, t)-h(x, y, t) \\
& e 2=\frac{1}{2}\{(h(x, y, t)-g(x, y))+(h(x-\Delta x, y, t)-g(x-\Delta x, y))\} \\
& g 2=h(x, y, t)-h(x-\Delta x, y, t) \\
& e 3=\frac{1}{2}\{(h(x, y+\Delta y, t)-g(x, y+\Delta y))+(h(x, y, t)-g(x, y))\} \\
& g 3=h(x, y+\Delta y, t)-h(x, y, t) \\
& e 4=\frac{1}{2}\{(h(x, y, t)-g(x, y))+(h(x, y-\Delta y, t)-g(x, y-\Delta y))\} \\
& g 4=h(x, y, t)-h(x, y-\Delta y, t)
\end{aligned}
$$

$\Delta x 、 \Delta y 、 \Delta t$ はそれぞれ $\mathrm{x} 、 \mathrm{y}$ 方向の格子間隔お

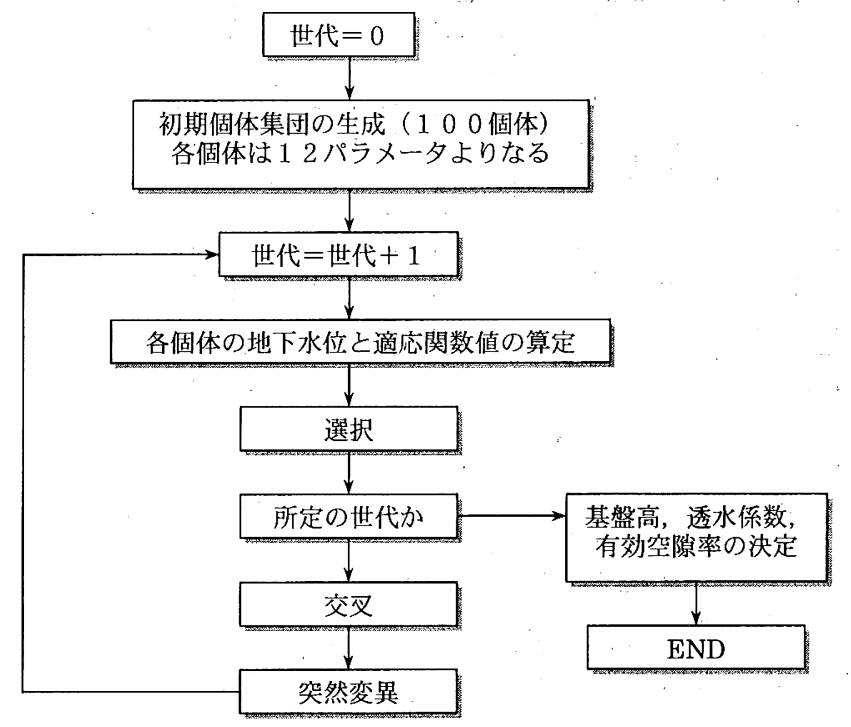

図 2 パラメータ同定のための流れ図

Fig. 2 Flow chart to identify the parameters 
よび時間間隔である。

次に、観測地下水位と得られた推定地下水位か ら式（2）によって100個体それぞれの適応関数值 を求める。この適応関数值は基盤高と地下水パラ メータが正しく設定されれば観測地下水位と推定 地下水位は一致してくるもので、この関数值が小 さいほど適応度が高いと評価される。

$$
f=\sqrt{\frac{1}{M \cdot N} \sum_{i=1}^{M} \sum_{j=1}^{N}\left(h_{i, j}-h_{i, j}^{\prime}\right)^{2}}
$$

ここに、

$M \quad$ : 観測井戸数、（図 1 のモデルでは）

$N$ : 各観測井戸の観測個数（時間的なもの で後述の適用例では)

$h^{\prime}$ : 観測地下水位

$i \quad:$ 観測井戸の番号

$j \quad$ : 時間的観測番号（ここでは 1 ４8）

次に適応度の高い個体が多く残るように選択を 行う。ここではトーナメント選択を用い、100の 個体を 2 回選択できるとして、任意の 2 個体の組 を100組作り、各組で適応関数值の小さい個体を 残す操作を行った。この選択方法では個体数は変 化しない。

次に交叉を行う。個体の 0 と 1 を遺伝子とみな して操作を行っている。交叉は100組の個体から 任意の 2 個体の50組について、交叉確率を 0.6 と して、0〜1の一様乱数を発生させ、0.6以下で あれば交叉操作を行った。その方法は、まず交叉 させる区間を乱数を用いて定め、その区間の遺伝 子を交叉させている。交叉区間 $3 \sim 6$ の場合の交 叉の一例を次に示す。

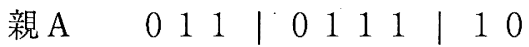 \\ \begin{tabular}{llll|llll|ll|l} 
親 $\mathrm{B}$ & 1 & 0 & 1 & 1 & 0 & 0 & 1 & 0 & 1
\end{tabular} \\ 子A $\quad 0111|1001| 10$ \\ 子 B $\quad 1001 \mid$\begin{tabular}{lllll|ll} 
& 0 & 1 & 1 & 1 & 0 & 1
\end{tabular}}

次に、突然変異の操作を行う。まず、交叉と同 様、乱数を用いて突然変異区間を定め、突然変異 確率0.1として、0〜 1 の一様乱数を発生させ 0.1 以下であれば変異区間の遺伝子について 0 は 1 に、 1 は 0 に組み替える操作（逆位）を行った。 この突然変異の考慮は局所解に陥ることを防ぐも ので、設定した範囲を広く探索しょうとするもの
である。変異区間が $2 \sim 4$ の場合の突然変異操作 の一例を次に示す。

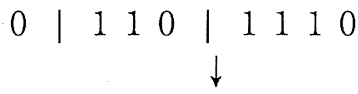

$$
\begin{aligned}
& \begin{array}{l|lll|llll}
0 & 0 & 0 & 1 & 1 & 1 & 1 & 0
\end{array}
\end{aligned}
$$

これらの一連の操作が終了すると、新たな個体 集団が生成され、この新しい集団に対して同様に 適応度の評価、選択、交叉、突然変異を2000世代 まで繰り返してゆき、適応度の高い個体、すなわ ち基盤高と地下水パラメータを得ている。

\section{2 次元自由地下水場への適用}

適用例として、図 3 に示す 2 つの設定基盤 (case1、2) の地下水場において、透水係数 $25.92 \mathrm{~m} /$ 日、有効空隙率 0.3 、東西の境界水位は 一定で南北の境界は不透水壁とし、図 4 に示す涵

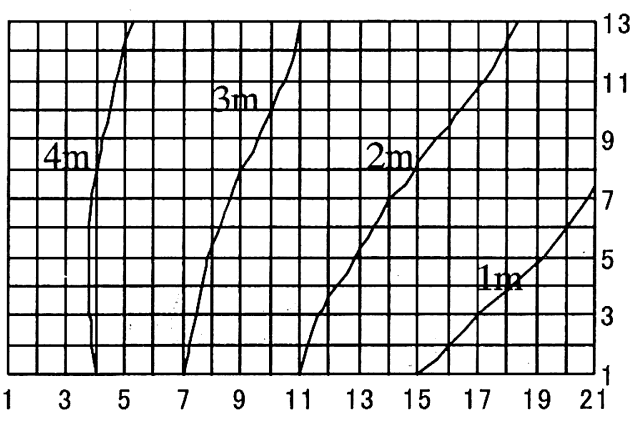

case 1

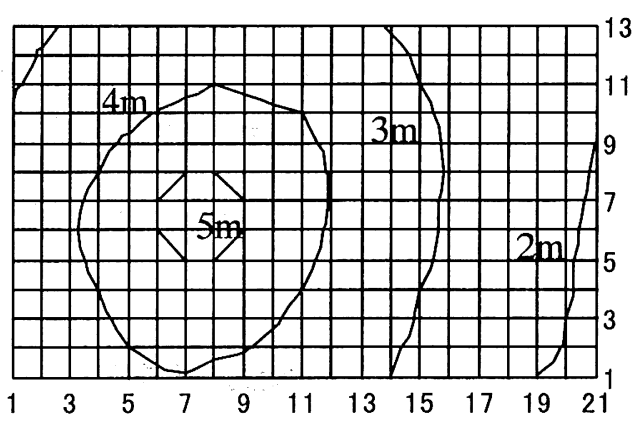

case 2

\section{図 3 設定基盤高}

Fig. 3 The distribution of lower boundary of aquifer given 
養量があったとして、式（1）を数值解析し、1つ の観測井戸について時間間隔 1 時間の48時間分の 地下水位を得、これを観測地下水位とした。な お、初期個体集団の作成には初期乱数を变化さ せ、10種類の初期個体集団を作成、同定し、適応 関数の最小のものを同定值とした。図 5 に設定基 盤の違いによる観測地下水位を示す。この図にお いて例えば凡例の2-1は基盤高は case1で井戸番号 2 の地下水位を示すものであるが、基盤高の違い による地下水位の差は比較的小さく、このわずか な違いによって、基盤高、透水係数、有効空隙率 を同定することになる。図 6、7に地下水位の観 測井戸数 7 、既知基盤高 5 の場合と比較のために 地下水位観測井戸数 4 、既知基盤高が 3 （求める パラメー夕総数は14）のときの同定基盤高を示 す。また、同定により得られた地下水パラメータ 值と適応関数值を表 1 に示す。case1、2ともに観 測井戸数が多い場合の方が適応関数值は小さく

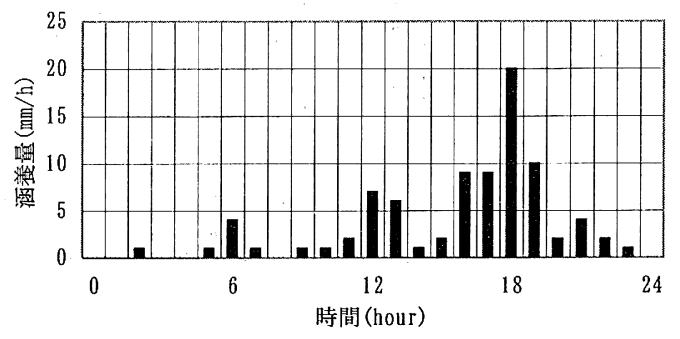

図 4 涵養量 $(\mathrm{mm} / \mathrm{h})$

Fig. 4 Recharge rate $(\mathrm{mm} / \mathrm{h})$
なっており、図 3 と図 $6 、 7$ を見比べると、地下 水位の観測井戸数および既知基盤高の多い場合の 方が設定基盤に近い分布となっている。これは観 測井戸数に応じて地下水位は観測地下水位に近く なる箇所が多くなり、適応関数值が小さくなって いるものと考えられる。透水係数についての䛊差 は case1で観測井戸数 7 の場合 $0.69 \%$ 、観測井戸 数 4 では $0.08 \%$ 、 case 2 で観測井戸数 7 の場合 $0.81 \%$ 、観測井戸数 4 では $5.25 \%$ でった。有効 空隙率についてはどの場合も設定值 0.3 泀定さ れている。有効空隙率は式 (1)より涵養量が既知 でなければ同定できないが、漸養量に見合うだけ 地下水位は上昇し、この上昇分を有効空隙率は表 すもので比較的精度よく同定されるものと考えら れる。これらの適用例では地下水パラメータの誤 差はいずれも小さく、適応関数值に応じて䛊差も 小さくなるものと考えられる。なお、case1の場 合では観測井戸数 4 、既知基盤高数 3 の場合の方 が地下水パラメータについての誤差が小さくなっ ているが、これは遺伝的アルゴリズムは多くの個 体群 (パラメータ群) から適合するパラメータを 探索するため、観測井戸数が少なくても良い精度 を示す場合があることを示している。しかしなが ら、一般には case20ように観測井戸数が多い場 合の方が正しく基盤高および地下水パラメータは 推定されると考えられる。

基盤高と地下水パラメータの同定において、境 界水位と少なくとも観測井戸は 1 つ以上必要であ り、観測井戸はできるだけ多く用いる必要があ

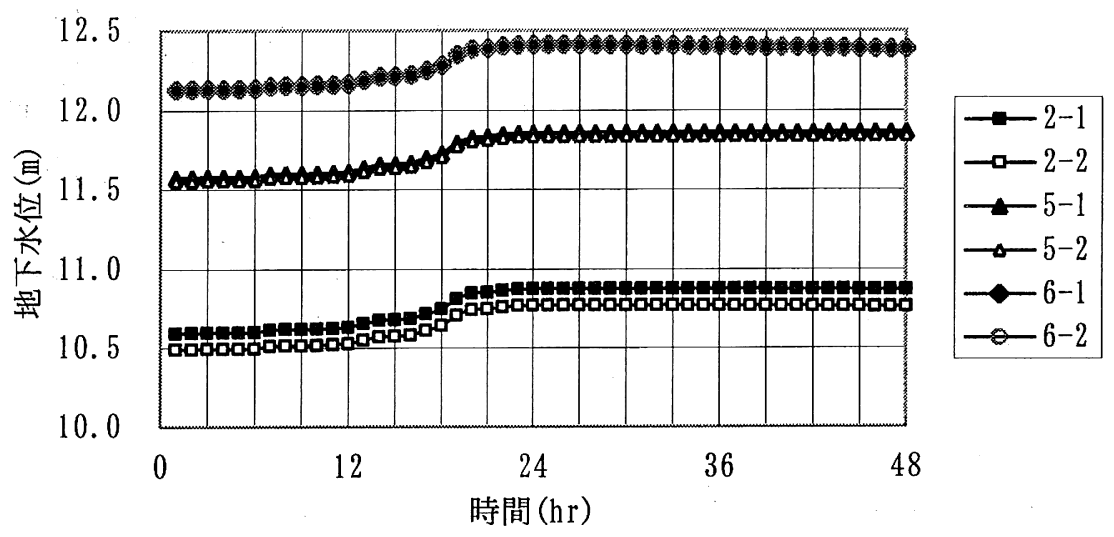

図 5 観測井戸番号 2, 5, 6 の観測地下水位

Fig. 5 Observation groundwater level of No.2, 5, 6 
る。観測井戸点の観測地下水位と推定地下水位が 一致していれば適応関数值は小さくなるが、観測 井戸数が少ない場合、解析領域全体についての地 下水位が一致しているとは限らないため、した がって、解の精度を上げるためには多くの観測井 戸が必要となる。なお、基盤高と地下水パラメー 夕のいずれも真值が分からないため、世代数とし ては適応関数值が変化しなくなる世代数を所定の 世代として、繰り返し計算し、最終值を同定值と する方法をとっている。

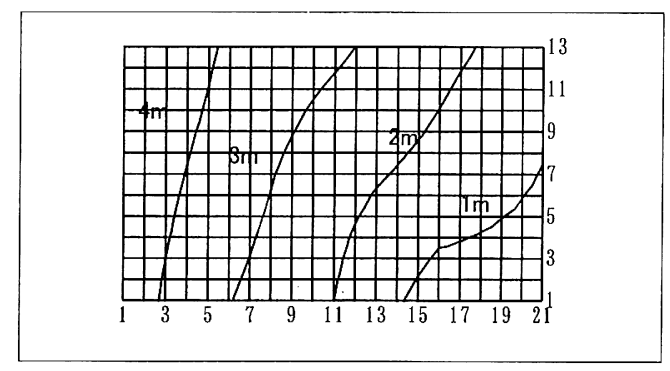

観測井戸数 7

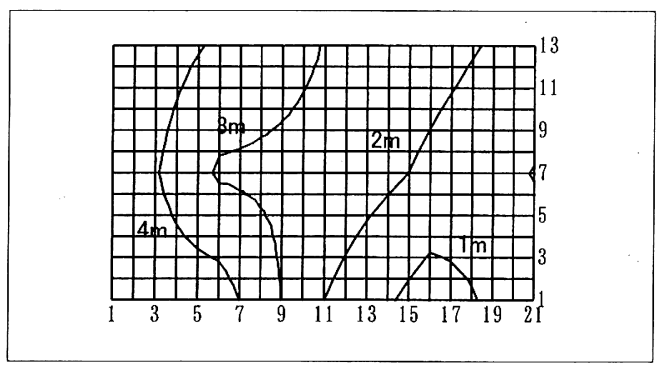

観測井戸数 4

図 6 同定基盤高（case1）

Fig. 6 The distribution of lower boundary of aquifer identified (case1)

\section{1 次元海岸帯水層の適用例}

図 8 に 1 次元の海岸帯水層モデルを示す。透水 係数は $100 \mathrm{~m} /$ 日、有効空隙率 0.3 、淡水密度 $1000 \mathrm{~kg} / \mathrm{m}^{3}$ 、塩水密度 $1025 \mathrm{~kg} / \mathrm{m}^{3}$ 、境界水位とし て、格子点番号 1 の海岸線では平均海水位 $0.0 \mathrm{~m}$ で、振幅 $0.6 \mathrm{~m}$ 、周期 12 時間の潮汐を与え、格子 点番号17の内陸部の境界水位は $4 \mathrm{~m}$ の一定值であ り、図 9 に示す涵養量があったとして、格子間隔 $50 \mathrm{~m}$ 、時間間隔30分として式（3）、（4）を用いて 非定常解 (小路ほか、1999) を算出し、各点48個 の観測水位を用いて基盤高と地下水パラメータを 同定した。なお、基盤高の既知点は 1 箇所で格子

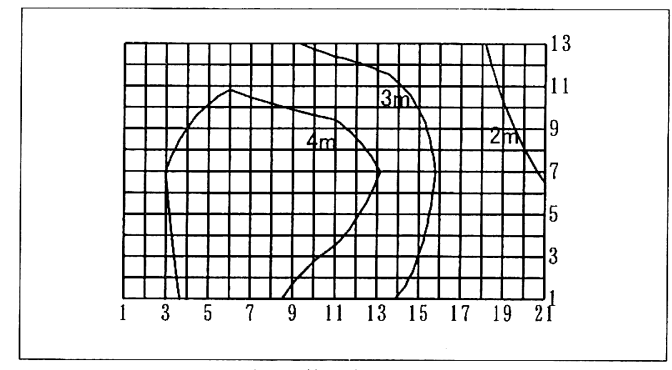

観測井戸数 7

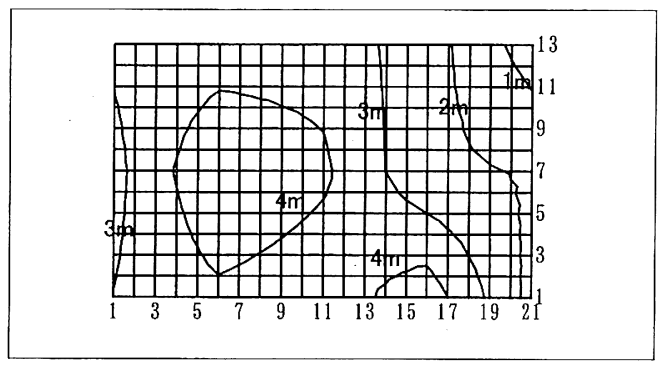

観測井戸数 4

図 7 同定基盤高 (case2)

Fig. 7 The distribution of lower boundary of aquifer identified (case2)

表 1 地下水パラメータの同定結果

Table 1 Results of identification of groundwater parameters

\begin{tabular}{c|r|r|r|r|r} 
& 観測井戸数 & 基地基盤高数 & 透水係数 (m/日) & 有効空隙率 & 適応関数值 $(\mathrm{m})$ \\
\hline 設定值 & & & 25.92 & 0.30 & \\
\hline case1 & 7 & 5 & 26.10 & 0.30 & 0.0002 \\
\hline case1 & 4 & 3 & 25.90 & 0.30 & 0.0008 \\
\hline case2 & 7 & 5 & 25.71 & 0.30 & 0.0003 \\
\hline case2 & 4 & 3 & 27.28 & 0.30 & 0.0011
\end{tabular}




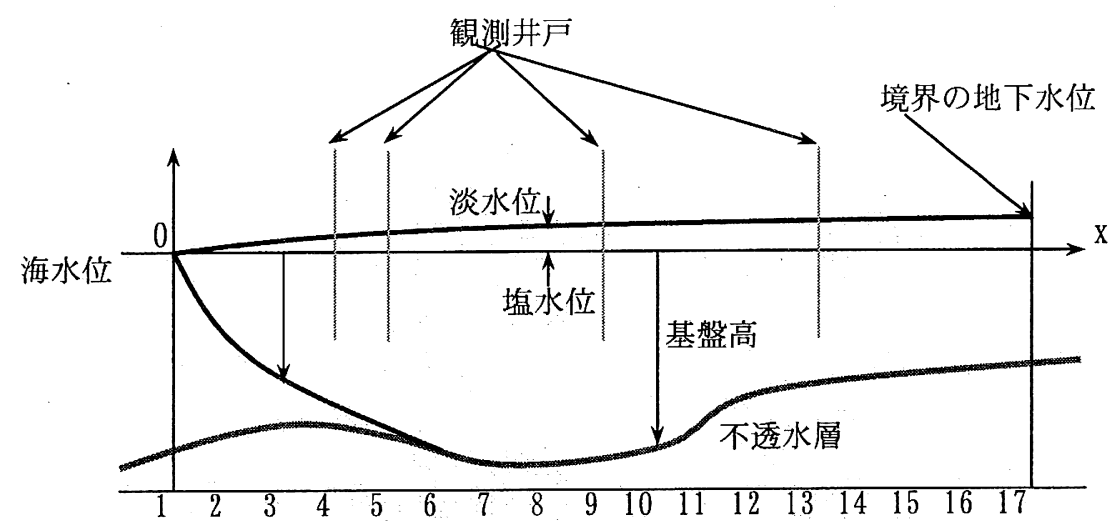

境界水位 1 ：振幅0.6m，周期12時間

$17: 4 \mathrm{~m}$ の一定水位

图 8 海岸帯水層モデル

Fig. 8 Model of coastral aquifer

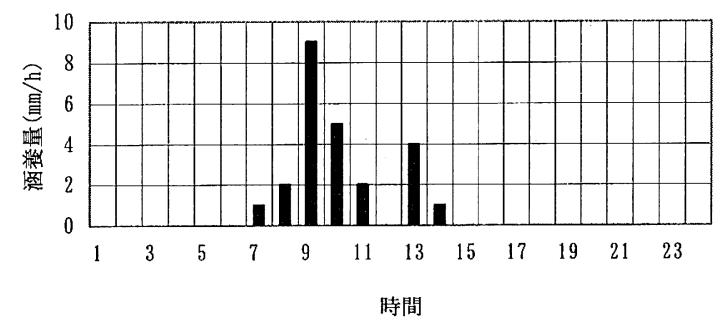

図 9 酒養量（海岸帯水層）

Fig. 9 Recharge rate (coastarl aquifer)

点番号 9 の-40m である。本適応例でも初期個体 集団は 10 種類を用意し、適応関数值の最小のもの を同定值としている。基盤高の探索範囲はー20 $-60 \mathrm{~m}$ 、透水係数の探索範囲は $30 \sim 120 \mathrm{~m} /$ 日、有 効空隙率の探索範囲は0.2 0.4と設定し同定を 行った。なお、海岸帯水層モデルでは基準高さを 平均潮位としているため、基盤高の位置は負の值 となっている。

$$
\begin{aligned}
& n \frac{\partial h_{f}}{\partial t}-n \frac{\partial h_{s}}{\partial t}=k \frac{\partial}{\partial x}\left\{\left(h_{f}-h_{s}\right) \frac{\partial h_{f}}{\partial x}\right\}+r \\
& n \frac{\partial h_{s}}{\partial t}=k \frac{\partial}{\partial x}\left\{\left(h_{s}-g\right) \frac{\partial}{\partial x}\left(\frac{\rho_{f}}{\rho_{s}} h_{f}+\frac{\rho_{s}-\rho_{f}}{\rho_{s}} h_{s}\right\}\right.
\end{aligned}
$$

ここに、

$h_{f}$ : 淡水位 $(\mathrm{m})$

$$
\begin{array}{ll}
h_{s} & \text { : 塩水位 }(\mathrm{m}) \\
g & \text { : 基盤高 }(\mathrm{m}) \\
\rho_{f} & \text { : 淡水密度 }\left(\mathrm{kg} / \mathrm{m}^{3}\right) \\
\rho_{s} & \text { : 塩水密度 }\left(\mathrm{kg} / \mathrm{m}^{3}\right) \\
k & \text { : 透水係数 }(\mathrm{m} / \text { 日) } \\
n & \text { : 有効空隙率 } \\
r & \text { : 涵養量 }(\mathrm{m} / \text { 日 })
\end{array}
$$

海岸線（格子点番号 1) 加内陸部へ直線的に 上昇している基盤高と逆に海岸線から直線的に下 降している基盤高について、眓10、11に観測井戸 数を 7 (格子点番号 $3 、 5 、 7 、 9 、 11 、 13 、$ 15)、 $4(3 、 7 、 11 、 15) 、 2(3 、 12)$ 箇所の 場合の同定基盤高を示す。また、表 2 に図10の基 盤高について観測井戸数の違いによる同定された 地下水パラメー夕、適応関数值、基盤高の誤差に ついての比較を示す。これらの図表より、観測井 戸数が多いほど、適応関数值は小さくなってお り、透水係数、有効空隙率ともに設定值に近く、 また、基盤高の誤差は小さくなり、基盤高は設定 基盤高にほほ一致している。罒10を見ると観測井 戸数が 2 の場合、基盤高が設定值より高く同定さ れている。この場合、地下水の流れる層が小さく なり、透水係数は設定值より大きく同定されたも のと思われる。また、逆に観測井戸数 4 の場合は 基盤高が設定基盤より低く推定されている。この 場合は地下水の流れる層が大きくなることから透 


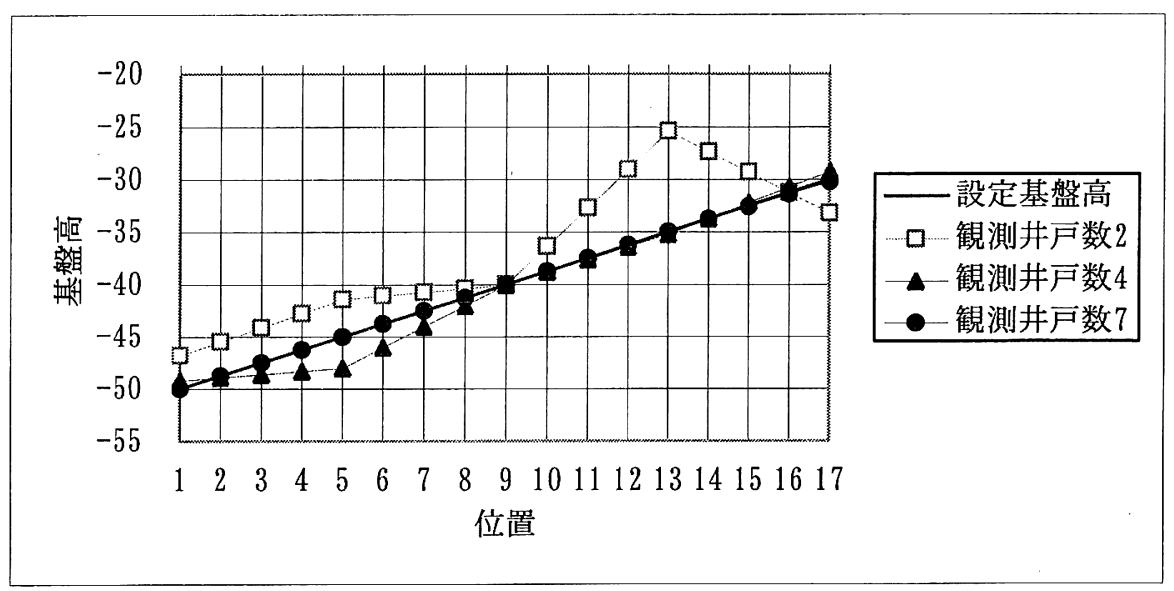

图10 設定基盤高と同定基盤高（case1）

Fig.10 The distribution of lower boundary of aquifer given and identified (case1)

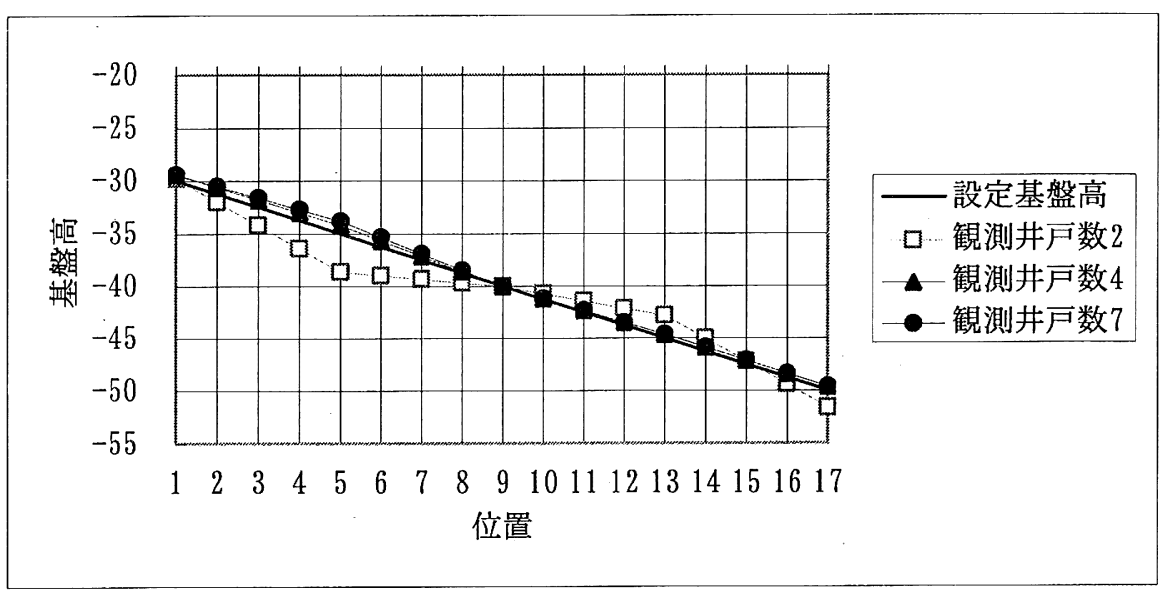

図11 設定基盤高と同定基盤高（case2）

Fig.11 The distribution of lower boundary of aquifer given and identified (case2)

\section{表 2 同定結果（海岸帯水層）}

Table 2 Results of identification of groundwater parameters (coastarl aquifer)

\begin{tabular}{l|r|r|r|r} 
& 設定値 & 観測井戸数2 & 観測井戸数4 & 観測井戸数7 \\
\hline 透水係数 $(\mathrm{m} /$ 日) & 100.00 & 107.46 & 99.84 & 98.75 \\
\hline 宔隙率 & 0.30 & 0.30 & 0.30 & 0.30 \\
\hline 適応関数值 $(\mathrm{m})$ & - & 0.032 & 0.038 & 0.018 \\
\hline 基盤高の誤差 $(\mathrm{m})$ & - & 5.603 & 1.606 & 0.100
\end{tabular}

水係数は小さく同定されたものと思われる。観測 井戸数が少なく、観測井戸間の距離がある場合は 観測井戸間で基盤高が正しく同定されない可能性 が高くなり、地下水パラメー夕には誤差が入る可 能性がでてくるものと思われる。しかしながら、
観測井戸数が多くなれば各観測井戸で推定地下水 位が観測地下水位に一致ししてくるために適応関 数值は小さく、基盤高抢よび地下水パラメータと もに正しく同定されるものと思われる。 


\section{5. まとめ}

本研究は地下水流について準一様流が適用でき るとして、観測誤差や準一様流の適用による誤差 については小さいまたは取り除かれているものと して、遺伝的アルゴリズムを用い観測地下水位に より基盤高、地下水パラメータを同時に同定する 手法を提示し、同定可能であること示した。観測 井戸数が多いほど基盤高、地下水パラメータは精 度よく同定されることを示した。有効空隙率は涵 養量による地下水位の上昇分を受け持つために比 較的精度よく同定されると考えられる。地下水位 は地下水が流れる層の高さと透水係数で規定され るために、基盤高の同定值が透水係数に、透水係 数の同定值が基盤高に影響する。したがって、既 存の井戸を用いるなど、多くの地下水位を測定す ることが必要であり、基盤高、透水係数の推定精 度は高くなるものと思われる。

\section{参考文献}

大西有三・井尻祐二（1986）: 不均一地盤における浸透 流の逆問題解析手法に関する基礎的研究、土木学会 論文集、第376号／III-6、PP.121-130.

奥野哲夫・鈴木 誠（1993）: 不圧地下水を対象とした 拡張カルマンフィルターによると薄い係数の空間分 布推定法、土木学会論文集、第469号 / III-23、 PP.93-102.

北野宏明（1994）：遺伝的アルゴリズム、産業図書、 PP.3-60.

河野伊一郎・西垣 誠 - 竹下祐二 (1989): 逆解析手法 を用いた被圧带水層における揚水試験結果の解析方
法、土質工学学会論文報告集、Vol.29、No.2、 PP.159-168.

小路順一、籾井和朗、藤野和德、國武昌人 (1999)：非 混合アプローチによる琉球石灰岩沿岸带水層への海 水侵入解析、農業土木学会論文集、第201号、 PP.355-362.

神野健二 (1990): 地下水污染の解析とモニタリングの 方法、水工学シリーズ $90-\mathrm{A}-6$, 土木学会水理委員 会.

竹下雄二 ·安井克豊・河野伊一郎（1997）：遺伝的アル ゴリズムを用いた多層带水層地盤における揚水試験 データの逆解析手法、地下水学会誌、第39巻第 4 号、 PP.313-325.

竹下祐二 (2000) : 地下水モデリングのための解析手法 の基礎3.5原位置透水試験による浸透特性值の推定、 地下水学会誌、第42巻第 2 号、PP.187-195.

藤間 聡（1989）：地下水パラメータの推定に関する基 礎的研究 (九州大学学位論文).

平野文昭（1991）: 地下水数值計算法（14）3-1、カルマ ンフィルターによる実時間同定問題、地下水学会誌、 第33巻第 4 号、PP.277-284.

藤野和徳 ・神野健二 (1994) : フーリ工級数と拡張カル マンフィルターによる地下水位と地下水パラメータ の推定、地下水学会誌、第36巻第 2 号、PP.155-167. 藤野和德（1997）：遺伝的アルゴリズムによるごみ収集 輸送計画、土木学会論文集 No.558／II-38、PP.139146.

本城勇介（2000）：地下水モデリングのための解析手法 の基礎3.4広域地下水解析モデルの逆解析、地下水学 会誌、第42巻第 2 号、PP.175-186.

(受付：2003年 2 月 17 日、受理：2003年 9 月 20 日) 